\title{
TOMASZ HOFFMANN
}

Poznań

\section{Kontrowersje wokół Traktatu lizbońskiego}

\section{1. „Okres refleksji” i prezydencja brytyjska w UE}

Po negatywnych wynikach referendów w sprawie Konstytucji dla Europy w maju i czerwcu 2005 r. we Francji i Holandii Unia Europejska znalazła się na przysłowiowym zakręcie. Powszechnie zaczęto zastanawiać się, co dalej z konstytucją europejską. Za kontynuowaniem procesu ratyfikacji w szczególności opowiedzieli się kanclerz Niemiec Gerhard Schröder oraz prezydent Francji Jacques Chirac. Przeciwko opowiedział się rząd Wielkiej Brytanii. Pisano nawet wprost, iż premier Tony Blair już podjął decyzję i ,jest zdeterminowany, by pogrzebać konstytucję"”.

Większość gazet opiniotwórczych w Europie pisała o swoistym kryzysie, który objął Unię Europejską. Co niektóre wskazywały nawet, iż odrzucenie konstytucji przez Francję i Holandię doprowadziło do poważnej utraty wiarygodności ambicji Unii Europejskiej, która chciała stać się ważnym aktorem na scenie globalnej².

W dniach 16-17 czerwca 2005 roku w Brukseli odbyło się posiedzenie Rady Europejskiej, na którym podjęto decyzję w sprawie przerwy nad dalszą ratyfikacją Traktatu Konstytucyjnego oraz w kwestii przesunięcia terminu jego wejścia w życie do końca października 2007 roku, czyli o rok w stosunku do wstępnie określonej daty ${ }^{3}$. Dodatkowy czas powinien być wykorzystany przez obywateli krajów Unii Europejskiej na dokonanie szerokiej debaty i refleksji na temat przyszłości Unii oraz dokładne zapoznanie społeczeństwa z dokumentem konstytucyjnym ${ }^{4}$.

1 lipca 2005 roku przewodnictwo w Unii objęła Wielka Brytania, odżyły więc propozycje czynione przez premiera T. Blaira, koncentrujące się na radykalnej przebudowie procesu integracji europejskiej ${ }^{5}$. Działania premiera dotyczyły przed wszystkim usprawnienia Wspólnej Polityki Rolnej tak, aby była ona korzystna dla Londynu. Tymczasem przywódcy państw członkowskich oczekiwali, że zajmie się on kwestiami najbardziej istotnymi, a mianowicie doprowadzeniem do ratyfikacji Traktatu Konstytucyjnego ${ }^{6}$. W tym samym czasie Unia Europejska stanęła przed negocjacjami w spra-

1 „Rzeczpospolita” z 6 czerwca 2005 r.

2 Zob. „The Guardian” z 4 czerwca 2005 r., podobnie: „International Herald Tribune” z 4-5 czerwca $2005 \mathrm{r}$.

3 Zob. Konkluzje Prezydencji, Bruksela 15 i 16 grudnia 2005 roku, http://www.consilium.europa.eu/ueDocs/cms_Data/docs/pressdata/PL/ec/87661.pdf, 21.09.2008.

4 Polska i Niemcy w Unii Europejskiej, Rola konfliktów i płaszczyzny wspótpracy, Poznań 2008, s. 43 .

5 Ibidem.

6 Zob. Nikt nie zniszczy nam rolnictwa, „Gazeta Wyborcza” (dalej: „GW”) z 12 lipca 2005 r., s. 20 . 
wie unijnego budżetu na lata 2007-2013. Premier T. Blair był początkowo obwiniany o brak postępów w uchwalaniu unijnej perspektywy finansowej. Bierność zarzucali mu szczególnie polscy politycy, uważając, że Wielka Brytania tylko traci czas ${ }^{7}$. Duży spór wywołały obniżone stawki podatku od towarów i usług, które miały być stosowane w Unii Europejskiej ${ }^{8}$, a także sam kształt unijnego budżetu, skrytykowany przez Polskę i inne państwa europejskie ${ }^{9}$.

Brytyjskiemu premierowi w trakcie prezydencji nie udało się zrealizować swoich postulatów. Nie zdołał wprowadzić w życie idei unijnego rynku usług, a także dokonać naprawy i przewartościowania unijnego budżetu oraz wprowadzić liberalizacji międzynarodowej wymiany w ramach Światowej Organizacji Handlu. Brytyjczycy nie wprowadzili żadnych nowych zmian w odniesieniu do Traktatu Konstytucyjnego. Z kolei T. Blair nie miał nawet żadnego racjonalnego pomysłu, w jaki sposób rozwiązać kryzys konstytucyjny w Europie. Tym samym brytyjskie przewodnictwo w Unii Europejskiej poniosło klęskę ${ }^{10}$.

Dyskusja nad Traktatem Konstytucyjnym powróciła na łono dyskursu europejskiego na początku 2006 roku, kiedy to Austria objęła przewodnictwo w Unii Europejskiej. Dla prezydencji austriackiej sprawa wznowienia procesu ratyfikacji Traktatu Konstytucyjnego była kwestią priorytetową ${ }^{11}$. Początkowo twierdzono, że Traktat nie jest dokumentem martwym. Wypowiedzieli się w tej kwestii liczni politycy w tym, między innymi, kanclerz Austrii Wolfgang Schüssel. Z kolei szefowa Ministerstwa Spraw Zagranicznych Austrii Ursula Plassnik stwierdziła wręcz, że nadszedł czas przejścia od diagnozowania do terapii. Konstytucja znajduje się pod głęboką warstwą śniegu. Nadchodzi jednak czas wiosny i zmiany klimatu ${ }^{12}$.

\section{Wpływ prezydencji niemieckiej na losy Traktatu Konstytucyjnego}

Objęcie rządów w Niemczech przez kanclerz Angelę Merkel stanowiło nową jakość w kwestiach Traktatu Konstytucyjnego. A. Merkel stwierdziła, że istnieje pilna potrzeba przyjęcia traktatu, którą winna poprzedzić nowa debata konstytucyjna w kwestii jego przyjęcia.

Swoimi przemyśleniami na temat traktatu podzieliła się z przewodniczącym Komisji Europejskiej José M. Barosso, który w pełni go zaakceptował. Z sugestiami niemieckiej kanclerz zapoznał się także prezydent L. Kaczyński, który stwierdził, że Polska odniesie się do tych propozycji w drugiej połowie niemieckiej prezydencji oraz przedstawi swoje oczekiwania wobec Traktatu Konstytucyjnego ${ }^{13}$.

Krótko po oświadczeniu Angeli Merkel polski premier J. Kaczyński również zmienił optykę postrzegania traktatu. Według niego Unia powinna być solidarna i partner-

7 Zob. K. Niklewicz, Polska ponagla Wielka Brytanię, „GW” z 8 września 2005 r., s. 22.

8 Zob. idem, Unijny spór o VAT, „GW” z 5 grudnia 2005 r., s. 28.

9 Zob. J. Pietras, To nie jest dobry budżet dla Polski i Europy, „GW” z 8 grudnia 2005 r., s. 29.

${ }_{10}$ Zob. „Rzeczpospolita” z 26 października 2005 r.

1 Zob. „Rocznik Strategiczny” 2005/2006, s. 152.

12 Zob. „Rzeczpospolita” z 10 stycznia 2006 r. oraz „Rzeczpospolita” z 12 stycznia 2006 r.

13 Zob. B. Koszel, Polska i Niemcy w Unii Europejskiej, s. 54. 
ska. Premier uważał, że Polska nie może stracić pozycji w układzie sił, który dawał jej Traktat nicejski. Nie wykluczał również pewnego kompromisu, który mógł być zawarty przez Polskę w kierunku przyjęcia nowego Traktatu reformującego ${ }^{14}$.

Obradująca w połowie grudnia 2006 roku w Brukseli Rada Europejska zdominowana została przez zbliżająca się prezydencję niemiecką w Unii Europejskiej, bezpieczeństwem energetycznym i kwestią rosyjskiego embarga na dostawy polskiego mięsa do tego kraju. Szczyt zajął się także Traktatem Konstytucyjnym. Przywódcy krajów Unii Europejskiej doszli do przekonania, iż dokument reformujący jest potrzebny i niezbędny Unii w celu jej dalszego rozwoju ${ }^{15}$.

W wywiadzie dla „Gazety Wyborczej” Andrew Duffen, brytyjski deputowany do Parlamentu Europejskiego, przekonywał, że Konstytucja potrzebna jest Europie podobnie, jak jej potrzebują Polacy i Brytyjczycy. Twierdził, że traktat ma spowodować skuteczniejsze działanie Unii Europejskiej.

A. Duffen był przeciwnikiem pisania nowego dokumentu. Obstawał przy starej, jednak trochę zmienionej konstytucji. Uważał, że należy unowocześnić polityki wspólnotowe, a także rozwiązać kwestie związane z podejmowaniem decyzji. Eurodeputowany sądził, że dużą rolę $\mathrm{w}$ procesie wypracowania nowej konstytucji odegrają Niemcy w trakcie ich przewodnictwa, a następnie Portugalia, aby w końcu decyzję mogli podjąć Francuzi ${ }^{16}$.

Oficjalnie objęcie prezydencji przez Niemcy było wzmocnieniem dalszych wysiłków w kwestii traktatu. Kanclerz Angela Merkel w przemówieniu w Parlamencie Europejskim stwierdziła, że „obowiązujące postanowienia traktatowe nie odpowiadają nowym rozmiarom Unii Europejskiej ani stojącym przed nią wyzwaniom,"17.

Według A. Merkel, Unia, działając na podstawie obecnych traktatów, nie może przyjąć do swojego grona nowych członków, a także nie jest zdolna do podejmowania niezbędnych decyzji ${ }^{18}$, stąd konieczne stało się wypracowanie nowego dokumentu, który jeszcze raz miał określić cele i działania Unii Europejskiej ${ }^{19}$. Dodała, iż dokument ten powinien być przyjęty jak najszybciej. Zdaniem A. Merkel w reanimację traktatu powinni włączyć się wszyscy szefowie rządów, którzy powinni wyznaczyć swoich pełnomocników. Będą oni, jak twierdziła, „szerpami”, czyli przewodnikami nowego dokumentu ${ }^{20}$.

Taki tryb prowadzenia negocjacji spotkał się z falą krytyki, dotyczącą braku przejrzystości, formułowaną nie tylko przez niektóre państwa członkowskie, ale także Parlament Europejski, komisarzy Komisji Europejskiej oraz niemieckie partie opozycyjne ${ }^{21}$.

14 Zob. J. Pawlicki, Kaczyński: Unia jak Ameryka, „GW” z 12 września 2006 r., s. 18.

15 Zob. K. Niklewicz, J. Pawlicki, Polskie weto jeszcze trochę, „GW” z 16-17 grudnia 2006 r., s. 8.

${ }_{16}$ Zob. D. Pszczółkowska, Dlaczego Unia potrzebuje europejskiej konstytucji, „GW” z 27 grudnia 2006 r., s. 10.

17 B. Koszel, Polska i Niemcy w Unii Europejskiej, op. cit., s. 48-57.

18 Zob. E. Górnicz, Geneza Traktatu z Lizbony, www.ukie.gov.pl, 16.10.2008.

${ }^{19}$ Cele te miano określić w Deklaracji Berlińskiej.

20 Zob. P. Wroński, Z konstytucja UE powoli, „GW” z 15 stycznia 2007 r., s. 4.

${ }^{21} \mathrm{Z}$ drugiej strony, prowadzenie negocjacji na poziomie specjalnych przedstawicieli szefów rządów i głów państw wydawało się skuteczne w znalezieniu rozwiązania patowej sytuacji, w której 
W Polsce prezydent Lech Kaczyński wyznaczył na polskich szerpów swojego doradcę Marka Cichockiego i sekretarza Urzędu Komitetu Integracji Europejskiej Ewę Ośniecką-Tamecką. W wywiadzie dla „Gazety Wyborczej” Marek Cichocki wątpił w szybkie przyjęcie nowego traktatu. Twierdził, że dużo zależy od wyborów, które odbędą się we Francji i Wielkiej Brytanii. M. Cichocki uważał, że wyniki tych wyborów mogą w istotny sposób pokrzyżować plan Angeli Merkel ${ }^{22}$.

W mediach również spekulowano, że wszelkie ustalenia związane z pracą i przyjęciem traktatu reformującego zależą od zmiany rządów we Francji i objęciu steru przez Nicolasa Sarkozyego oraz zmiany władzy w Wielkiej Brytanii i objęcia przywództwa przez Gordona Browna ${ }^{23}$.

W tych okolicznościach zadaniem polskich polityków było w odpowiedni sposób starać się wpływać na przebieg wydarzeń i nie dopuścić do zepchnięcia Polski do rangi kraju drugiej kategorii. Należało podjać zdecydowane kroki w kierunku zainicjowania debaty o traktacie konstytucyjnym. Dokonała tego Platforma Obywatelska, która wyznaczyła Jacka Saryusza-Wolskiego na pełnomocnika ds. debaty społecznej w kwestii traktatu reformującego. Inicjatywa ta spotkała się z życzliwym przyjęciem prezydenta Lecha Kaczyńskiego ${ }^{24}$.

Spór natomiast wywołała kandydatura J. Saryusza-Wolskiego na szefa Komisji Spraw Zagranicznych w Parlamencie Europejskim, który wyraźnie pokazał różnice w postrzeganiu polityki zagranicznej między Platformą Obywatelską a Prawem i Sprawiedliwością. Tym samym w kraju zaczęto coraz intensywniej dyskutować o traktacie.

29 stycznia 2007 roku polscy szerpowie udali się do Berlina, gdzie odbyli poufne rozmowy w Urzędzie Kanclerskim ${ }^{25}$. Spotkali się z niemieckim negocjatorem Uwe Corsepiusem, który prowadził rozmowy z wszystkimi szerpami narodowymi w kwestii Traktatu Konstytucyjnego.

Polscy wysłannicy mieli przedstawić kwestie sporne, które koncentrowały się wokół nazwy Traktatu Konstytucyjnego, systemu liczenia głosów, a także statusu europejskiego ministra spraw zagranicznych ${ }^{26}$. Swoje wątpliwości wyraził także prezydent Lech Kaczyński, przebywając w Dublinie w dniach 18-20 lutego 2007 roku. W trakcie wygłoszonego wykładu w Narodowym Forum Europejskim L. Kaczyński, domagał się istotnych zmian. Stwierdził, że polskie władze są entuzjastami Unii Europejskiej, ale „Europa jest ciaggle Europą narodów” ${ }^{27}$. Prezydent uważał, że traktat przyjęty w obecnym kształcie mógłby zaszkodzić niektórym państwom, w tym Polsce. Nie ukrywał, iż Unia Europejska równie dobrze mogłaby funkcjonować bez traktatu ${ }^{28}$.

znalazła się Unia Europejska po nieudanych referendach we Francji i Holandii. Zob. J. C. Piris, The Constitution for Europe, op. cit., s. 122.

${ }^{22}$ Zob. P. Wroński, Z konstytucja UE powoli „GW”, ed. cit., s. 4.

23 Zob. K. Szymański, Eurokonstytucja na Polska miare, „GW” z 16 stycznia 2007 r., s. 18.

24 Zob. R. Kalukin, PO: Unia na sztandar, „GW” z 19 stycznia 2007 r., s. 4.

25 Zob. B. Koszel, Polska i Niemcy w Unii Europejskiej, op. cit., s. 60.

26 Zob. J. Pawlicki, A. Leszczyński, Polaków rozmowy o eurokonstytucji, „GW” z 29 stycznia 2007 r., s. 8.

27 B. Koszel, Polska i Niemcy w Unii Europejskiej, op. cit., s. 60.

28 Ibidem. 
W wywiadzie dla „Gazety Wyborczej” Reinhard Schweppe stwierdził, że Unia Europejska potrzebuje nowego traktatu reformującego. Odnosząc się wprost do postulatów polskich, stwierdził, iż w Polsce najczęstsza krytyka traktatu dotyczy kwestii głosowania w Radzie Unii Europejskiej, która jest korzystniejsza w Traktacie nicejskim. R. Schweppe jednak podawał w wątpliwość, czy aby na pewno tak jest ${ }^{29}$. Tymczasem uzgodnienia w sprawie traktatu nie posuwały się do przodu. Twierdzono nawet, że Niemcy chcą w zbyt szybkim tempie osiągnąć duże postępy. Berlin naciskał na Polskę, żeby zgodziła się na utrzymanie zasady podwójnej większości głosów w procesie decyzyjnym. Z kolei Polska chciała, aby każde państwo dostało tyle głosów, ile wynosi pierwiastek kwadratowy z liczby jego ludności. Opór polskiego rządu miał być przełamany podczas wizyty A. Merkel 16 marca 2007 roku $^{30}$.

Z wizytą tą wiązano duże nadzieje. Kanclerz A. Merkel miała wysondować polskie władze w kwestii Traktatu Konstytucyjnego. W wykładzie wygłoszonym na Uniwersytecie Warszawskim mówiła o swojej wizji Europy. Kanclerz stwierdziła, że pragnie „Unii silnej, sprawnej i innowacyjnej”" ${ }^{\text {„2. }}$

Dalsze rozmowy były prowadzone z prezydentem L. Kaczyńskim w jego rezydencji na Helu. W efekcie prezydent zgodził się, by projekt Traktatu Konstytucyjnego był podstawą rozmów o nowym traktacie Unii Europejskiej. Prezydent obiecał, że Polska intensywnie włączy się w prace nad nowym traktatem, jednak nie zmieni zdania odnośnie kwestii nicejskiego systemu głosowania. Za zgodę na eurokonstytucję Polska mogła liczyć na zapis o solidarności energetycznej Unii Europejskiej ${ }^{32}$.

Wizytę Angeli Merkel i jej spotkanie z L. Kaczyńskim ocenił Tadeusz Mazowiecki, który stwierdził, że spotkanie to na pewno ociepliło stosunki polsko-niemieckie, które od czasu objęcia rządu przez Prawo i Sprawiedliwość nie należały do udanych ${ }^{33}$. Ze spotkania zadowolona była także kanclerz Angela Merkel. Mówiła, że przeprowadzono dobre pertraktacje i wkrótce odbędą się polsko-niemieckie konsultacje w sprawie traktatu $^{34}$.

Stanowiska partii politycznych w kwestii systemu liczenia głosów ulegały powolnej zmianie. Platforma Obywatelska postanowiła odejść od wygłoszonego kiedyś hasła „Nicea albo śmierć”. J. Saryusz-Wolski zakomunikował, że Platforma Obywatelska gotowa jest rozmawiać o systemie nicejskim. Był to pierwszy asumpt do tego, iż partie tak zaciekle broniące fundamentalnego hasła powoli zaczynają się z niego wycofywać ${ }^{35}$.

W Sejmie zaprezentowano także mapę drogową w sprawie traktatu. Minister spraw zagranicznych Anna Fotyga przedstawiła informacje o polskim stanowisku odnośnie traktatu oraz w sprawie Deklaracji Berlińskiej ${ }^{36}$. Owa deklaracja miała rozpoczać dyskusję nad nową konstytucją. Minister uważała, że Polska powinna wziąć udział w de-

29 Ibidem.

30 Zob. B. T. Wieliński, K. Niklewicz, Konstytucja w rozsypce, „,GW” z 24-25 lutego 2007 r., s. 6.

31 B. Koszel, Polska i Niemcy w Unii Europejskiej, op. cit., s. 61.

32 Zob. W. Sadurski, Europie kamień spadt z serca, ,GW” z 27 lutego 2007 r., s. 20.

33 Ibidem.

34 Niemcy zadowoleni, ,GW” z 28 lutego 2007 r., s. 20.

35 Zob. W. Sadurski, Europie kamień spadt z serca, „GW” ed. cit., s. 20.

36 Zob. „Rocznik Polskiej Polityki Zagranicznej”, Warszawa 2008, s. 47. 
bacie poświęconej traktatowi. Jednocześnie oświadczyła, iż co prawda traktat jest potrzebny Polsce, jednak jest on obecnie przeregulowany ${ }^{37}$.

W trakcie dyskusji można było zauważyć rysujący się kompromis wśród partii, dotyczący systemu głosowania. W wywiadzie dla „Gazety Wyborczej” Danuta Hübner utrzymywała, że „dobrze się stało, iż Polska wreszcie opowiedziała się za reanimacją Traktatu Konstytucyjnego". Polska komisarz skrytykowała obstawanie przez Prawo i Sprawiedliwość przy systemie podziału głosów i twierdziła, że od tego postulatu są ważniejsze kwestie, jak choćby przyszłość Polski w Unii ${ }^{38}$.

Innego zdania był były prezes Trybunału Konstytucyjnego Marek Safjan, który uważał, że rząd ma obowiązek dotrzymać umowy i ratyfikować odrzucony przez Francję i Holandię dokument. Sądził, że ratyfikacja powinna nastąpić w ogólnonarodowym referendum, które winno być zwołane jak najszybciej39.

Niemcy uważały, że traktat powinien zostać przyjęty na czerwcowym szczycie Rady, a następnie dopracowany w trakcie Konferencji Międzyrządowej ${ }^{40}$. Nastrój obywateli niemieckich zakłóciły dwa kraje, które poddawały w wątpliwość datę wejścia Traktatu Konstytucyjnego. Prezydenci Czech i Polski oficjalnie przeciwstawiali się dacie 2009 roku jako terminowi jego wejścia w życie. Prezydent L. Kaczyński stwierdził, że najlepszą datą byłby rok 2011. Zakwestionował istotę i pozycję unijnego ministra ds. zagranicznych oraz stałego przewodniczącego Unii Europejskiej ${ }^{41}$. Podobnego zdania był prezydent Czech.

Pod koniec marca 2007 roku Polska złożyła własną propozycję reformy Traktatu Konstytucyjnego. Polegała ona na wprowadzeniu nowego systemu ważenia głosów, zwanego systemem pierwiastkowym ${ }^{42}$. System ten opierał się na matematycznej zasadzie Penrose'a z 1946 roku, czyli pierwiastku kwadratowym z liczby ludności. Według polskiej propozycji decyzja w Radzie Unii Europejskiej byłaby przyjmowana, gdyby stała za nią ponad połowa krajów, czyli 14 z 27, dysponujących 62 procentami liczby głosów wyliczonych pierwiastkowo ${ }^{43}$. Na systemie pierwiastkowym zyskałyby kraje średnie, takie jak Hiszpania, Polska, Rumunia i Holandia, a straciły największe: Niemcy, Francja, Włochy i Wielka Brytania ${ }^{44}$.

Zaproponowana koncepcja pierwiastkowa miała być w rękach polskich „szerpów” narzędziem do zablokowania dalszych rozmów w kwestii Traktatu Konstytucyjnego ${ }^{45}$. Nie ulega jednak wątpliwości, że, jak pisze Bogdan Koszel, koncepcja ta była bardziej sprawiedliwa i lepiej oddawała ducha unijnej solidarności słabszych z silniejszymi. System ten korygował pewną nierównowagę w Unii Europejskiej, jaką wprowadzał

37 Zob. Polska elastyczna w sprawie traktatu konstytucyjnego, „GW” z 3-4 marca 2007 r., s. 5.

38 Zob. K. Niklewicz, Polska w UE nie może tylko blokować, „GW” z 5 marca 2007 r., s. 12.

39 Zob. M. Safjan, Żadajmy referendum o eurokonstytucji, „GW” z 9 marca 2007 r., s. 23.

40 Zgodnie z ustaleniami traktat miał zacząc obowiązywać od 2009 roku. Zob. B. Koszel, Polska i Niemcy w Unii Europejskiej, op. cit., s. 63.

41 Zob. „Rzeczpospolita” z 27 marca 2007 r.

42 Zob. J. Barcz, Przewodnik po Traktacie z Lizbony, s. 90.

43 Zob. J. Pawlicki, Polska gra o głosy w UE, „GW” z 29 marca 2007 r., s. 9. Zob. też: „Rzeczpospolita" z 30 marca $2007 \mathrm{r}$.

${ }_{44}$ Zob. B. Koszel, Polska i Niemcy w Unii Europejskiej, op. cit., s. 64.

45 Zob. J. Pawlicki, K. Niklewicz, Europa nie wierzy w weto, „GW” z 30 marca 2007 r., s. 10. 
Traktat nicejski, faworyzujący Polskę i Hiszpanię kosztem Niemiec, jak również Traktat Konstytucyjny, dający uprzywilejowaną pozycję czwórce największych państw kosztem Polski i Hiszpanii ${ }^{46}$.

Znany politolog Klaus Bachmann potwierdził opinię, że system pierwiastkowy nie jest zły, jednak, jak zauważył, odbiera największym państwom, takim jak Niemcy, Francja, Włochy i Wielka Brytania, dużą liczbę głosów ${ }^{47}$. To z kolei może spowodować sytuację, w której zastosowanie przez Polskę weta sprawi jej wiele kłopotów. Autor wysnuł tę tezę na podstawie teorii „paradoksu słabości”, który polega na tym, że im słabszy rząd, tym bardziej inne kraje gotowe są uwzględnić jego postulaty. Rząd Kaczyńskiego miał poparcie polityczne i społeczne, a to z kolei powodowało, że traktat z zapisami o podwójnej większości zostanie przyjęty przez partie opozycje oraz społeczeństwo. Na nic jednak zdał się upór rządu w kwestii zasady pierwiastkowej, bowiem gabinet Kaczyńskiego nie mógł skorzystać z „paradoksu słabości” i przeforsować swoją propozycję ${ }^{48}$.

W rozpoczynającej się debacie europejskiej w kwestii traktatu, kanclerz A. Merkel chciała, by nowy dokument był pewnym krokiem na drodze do Europejskiej Federacji. Dążyła także do tego, by wszedł w życie w 2009 roku. Z kolei stanowisko Polski było nieugięte. Premier i prezydent Kaczyńscy upierali się, aby w traktacie znalazł się mechanizm osłabiający pozycję Niemiec. Ponadto sądzili, że traktat powinien zacząć obowiązywać od 2011 roku $^{49}$. Podobnie wypowiadała się minister spraw zagranicznych Anna Fotyga ${ }^{50}$. Wygłaszając w Sejmie coroczne exposé o polityce zagranicznej Polski, twierdziła, że z przyjęciem traktatu nie należy się śpieszyć, bowiem nie jest on dopracowany, a Polska optuje za dobrym merytorycznie dokumentem ${ }^{51}$. W mediach pojawiały się opinie, że Niemcy, którym bardzo zależy na przyjęciu traktatu reformującego, będą musieli coś w zamian Polsce zaoferować ${ }^{52}$.

Polska liczyła na wsparcie Czech w batalii o system ważenia głosów. W połowie maja 2007 roku, na poufnej konferencji w Urzędzie Kanclerskim w Berlinie, M. Cichocki i E. Tamecka-Ośniecka przekazali przewodzącym Niemcom pisemne uwagi rządu polskiego w kwestii eurokonstytucji ${ }^{53}$.

Szerpowie w swoim stanowisku przedstawili trzy możliwe kompromisy. Pierwszy miał polegać na tym, aby Niemcy zobowiązali się przez około 10 lat nie korzystać w głosowaniach ze swojego potencjału ludności, a do celów obliczeniowych go nawet zmniejszyć. To obniżyłoby ich potencjał i Polska mogłaby wzmocnić swoją pozycję w Unii Europejskiej kosztem Berlina.

Drugi kompromis miałby się koncentrować na wzmocnieniu wywalczonego przez Polskę w 2004 roku tzw. hamulca bezpieczeństwa, który umożliwiałby odwlekanie de-

\footnotetext{
46 Zob. B. Koszel, Polska i Niemcy w Unii Europejskiej, op. cit., s. 64. Zob. też: „Rzeczpospolita” z 30 marca $2007 \mathrm{r}$.

47 Niemcy na podstawie reformy pierwiastkowej mogły stracić prawie 60 procent głosów.

48 Zob. K. Bachmann, Dobry pomyst w zlym momencie, „GW” z 11 kwietnia 2007 r., s. 19.

49 Zob. J. Pawlicki, Pakt Kaczyński - Merkel, „GW” z 13 kwietnia 2007 r., s. 14.

50 Por. L. Jesień, Polityka Polski w Unii Europejskiej, op. cit., s. 43.

51 Zob. idem, Quo vadis, Fotygo?, „GW” z 12-13 maja 2007 r., s. 3.

52 Zob. idem, Bruksela chce kompromisu z Polska, „GW” z 17 maja 2007 r., s. 11.

53 Zob. B. Koszel, Polska i Niemcy w Unii Europejskiej, op. cit., s. 65.
} 
cyzji przez „rozsądny czas”, jeśli kwestionowałyby go państwa zamieszkane przez ponad 26,25 procent ludności. Dzięki temu rozwiązaniu państwo polskie mogłoby w sojuszu z mniejszymi i średnimi państwami blokować przyjęcie niekorzystnej dla siebie decyzji.

Ostatnie rozwiązanie polegałoby na tym, iż w zamian za pogodzenie się z zasadą podwójnej większości, Polska mogłaby dostać kilka dodatkowych mandatów w Parlamencie Europejskim ${ }^{54}$.

Mając świadomość pewnego odosobnienia na unijnej arenie, politycy polscy zaczęli upowszechniać własny pomysł systemu ważenia głosów i starali się do tego przekonać inne państwa. Dość silne wsparcie rząd otrzymał w tej kwestii od Sejmu, który wyraził przekonanie, iż nowy traktat powinien być kompromisem wzmacniającym Unię Europejską̧ ${ }^{55}$.

Tym samym Sejm dał mandat rządowi do wystąpienia na szczycie w Brukseli z propozycją pierwiastka kwadratowego ${ }^{56}$. Za uchwałą autorstwa opozycyjnej PO głosowało 377 posłów z PiS, PO, Samoobrony, LPR i innych partii. Przeciw było 43 z SLD, oraz jeden poseł niezrzeszony. Wstrzymał się 1 poseł z PO, 1 z SLD, 1 z LPR oraz dwóch posłów niezrzeszonych ${ }^{57}$.

$\mathrm{Na}$ francuskiej scenie politycznej w tym samym czasie zaszły radykalne zmiany. Prezydentem został Nicola Sarkozy, który miał zupełnie inną wizję traktatu reformującego $^{58}$. W większości spraw zgadzał się z postulatami Polski, co, jak podkreślali komentatorzy, było ewenementem we francuskiej polityce zagranicznej. N. Sarkozy bardzo sobie cenił współpracę z Niemcami. Podczas swojej pierwszej (po zaprzysiężeniu) wizycie w Berlinie stwierdził, iż współpraca z A. Merkel jest dla niego ,święta”, 59 .

W Polsce z kolei spekulowano, że nowy „tandem Francja-Niemcy”, umiejętnie wykorzystany, może dobrze służyć państwu w kwestiach przyszłości Unii Europejskiej. W czerwcu prezydent L. Kaczyński poinformował N. Sarkozy’ego, iż Polska opowiada się w traktacie za pierwiastkowym systemem głosów, a także wyraził przekonanie, że uda się w tej sprawie znaleźć wyjście kompromisowe. Prezydent Francji próbował jednak przekonać polskiego prezydenta do rezygnacji z zasady pierwiastkowej i zawarcia kompromisu $^{60}$. Zarówno prezydent, jak i premier optowali, że nie zrezygnują z idei pierwiastka kwadratowego ${ }^{61}$.

Negatywny odzew na polskie propozycje w sprawie „pierwiastka kwadratowego" w 26 krajach Unii Europejskiej spowodował, że rząd zaczął powoli mówić o kompro-

54 Zob. J. Pawlicki, Polska nie musi w Unii stać pod ściana, „GW” z 24 maja 2007 r., s. 14.

55 Zob. Sprawozdanie stenograficzne Sejmu z 43. posiedzenia w dniu 15 czerwca 2007 roku, http://parl.sejm.gov.pl/StenoInter5.nsf/0/1845EEA337487F5BC1257308007F4A2B/\$file/43_d_ksiazka.pdf,21.10.2008.

56 B. Koszel, Polska i Niemcy w Unii Europejskiej, op. cit., s. 65.

57 D. Uhlig, Sejm popart walkę o pierwiastek, „GW” z dnia 16-17.06.2007 r., s. 4. Zob. 43. posiedzenie Sejmu Rzeczypospolitej Polskiej w dniach 12, 13, 14 i 15 czerwca 2007 r. http://orka.sejm.gov.pl/SQL.nsf/glosowania?OpenAgent\&5\&43\&67, materiał pobrano dnia 21.10.2008 r.

58 Zob. „Le Monde” z 26 czerwca 2007 r., s. 10.

59 M. Zaborowski, Sarkozy - szansa dla Polski, „GW” z 25 maja 2007 r., s. 13.

60 Zob. A. Michnik, J. Kurski, Francja solidarna z Polska, „GW” z 14 czerwca 2007 r., s. 16.

${ }^{61}$ Zob. J. Pawlicki, Szczyt UE: kompromis albo śmierć, „GW” z 29 maja 2007 r., s. 11. 
misie. Kompromis ten osłabiał polską pozycję przetargową na szczycie w Brukseli. Zauważono, że nie tylko Polska będzie głównym problemem na brukselskim szczycie, ale także może nim być Wielka Brytania. Londyn od początku jasno i twardo stawiał warunki, twierdząc, iż nie zaakceptuje traktatu, który pozwoli Karcie Praw Podstawowych zmienić w jakikolwiek sposób prawo brytyjskie. Brytyjczycy nie chcieli zrezygnować z możliwości kontrolowania swego prawa oraz systemów wymiaru sprawiedliwości i policyjnego 62 .

Twierdzono, że jeśli dojdzie do starcia Merkel z Blairem, prezydent L. Kaczyński pozwoli ,umrzeć” Brytyjczykom za wykreślenie Karty Praw Podstawowych, co z kolei może spowodować, że trudno będzie sobie wyobrazić Unię Europejską bez Wielkiej Brytanii ${ }^{63}$.

Brukselski szczyt rozpoczął się 21 czerwca 2007 roku. Na samym początku obfitował w dramatyczne przemówienie L. Kaczyńskiego, który wyliczył polskie straty wojenne w czasie okupacji wojennej i ich wpływ na obecną sytuację w kraju. Po północy, po spotkaniu L. Kaczyńskiego z A. Merkel, N. Sarkozym i prezydentem Litwy V. Adamusem, zarysowało się wstępne porozumienie co do przyszłości traktatu reformującego. Polska zaproponowała odstąpienie od formuły pierwiastkowej i przedłużenie systemu nicejskiego do $2020 \mathrm{roku}^{64}$.

To z kolei nie spodobało się Belgom. W efekcie, drugiego dnia szczytu, premier Luksemburga J. C. Juncker zaproponował utrzymanie nicejskiego systemu głosowania do 2014 roku z możliwością wprowadzenia okresu przejściowego do 2017 roku. Z kolei z tą propozycją nie zgadzał się prezydent L. Kaczyński, który konsultował tę kwestię telefonicznie $\mathrm{z}$ bratem Jarosławem.

W konsekwencji A. Merkel ogłosiła, że rozpocznie Konferencję Międzyrządową bez udziału Polski. Ta propozycja napotkała na opór Czechów i Litwinów. Po kolejnej serii rozmów Sarkozy’ego, T. Blaira, K. C. Junckera, i J. L. Zapatero z L. Kaczyńskim oraz telefonicznych konsultacjach z Warszawą nadeszła zgoda premiera Kaczyńskiego ma przedstawione propozycje $\mathrm{e}^{65}$.

23 czerwca 2007 roku, po trzydziestu sześciu godzinach negocjacji, Rada Europejska w Brukseli przyjęła jednomyślnie konkluzje prezydencji niemieckiej dotyczące reformy traktatowej oraz mandat dla Konferencji Międzyrządowej ${ }^{66}$. A. Merkel oświadczyła, że „negocjacje zajęły wiele czasu, ale uzyskaliśmy to, co chcieliśmy; bardzo szczegółowy i precyzyjny mandat" ${ }^{\prime 67}$. Kanclerz przyznała, że ,nie było to łatwe, bowiem wszyscy musieli uczynić jakieś ustępstwa, [...] jednak liczy się rezultat"68.

62 Zob. idem, Niech Blair umiera, a nie my, „GW” z 20 czerwca 2007 r., s. 11.

63 Ibidem.

64 Zob. Agreement on IGC mandate for finalizing and adopting New Union Treaty, „Agence Europe" z 24 czerwca $2007 \mathrm{r}$.

65 Zob. B. Koszel, Polska i Niemcy w Unii Europejskiej, op. cit., s. 70. Zob. też: M. Wojciechowski, A jednak się dogadali, „GW” z 23-24 czerwca 2007 r., s. 15.

${ }^{66}$ Por. „Rocznik Strategiczny” 2007/2008, s. 116.

67 Agreement on IGC mandate for finalizing and adopting New Union Treaty, op. cit. Por. K. Bachamnn, Żelazna Angela i Smok Wawelski, „GW” z 25 czerwca 2007 r., s. 18.

${ }^{68}$ Agreement on IGC mandate for finalizing and adopting New Union Treaty, op. cit. Podobnie: B. Koszel, Polska i Niemcy w Unii Europejskiej, op. cit., s. 70 oraz: „Rzeczpospolita” z 23 czerwca $2007 \mathrm{r}$. 
Zgodnie z konkluzjami prezydencji, Rada Europejska postanowiła zwołać Konferencję Międzyrządową i wezwała prezydencję portugalską do jej rozpoczęcia przed końcem lipca 2007 roku. Krótko po szczycie prezydent L. Kaczyński stwierdził, że największym sukcesem polskich negocjatorów w Brukseli było porozumienie się co do dalszego funkcjonowania korzystnego dla Polski systemu nicejskiego, który ma obowiązywać przez około 10 lat. Potem będzie obowiązywać system podwójnej większości, ale ze wzmocnionym mechanizmem z Joaniny ${ }^{69}$. W podobnym tonie wypowiedział się premier J. Kaczyński, który mówił wręcz o polskiej mocy blokującej, wynikającej z Joaniny ${ }^{70}$.

Tymczasem urzędnicy brukselscy twierdzili, że w mandacie ze szczytu, na który zgodziła się Polska, zapisano, że po 2017 roku mechanizm z Joaniny pozwoli blokować decyzje przez „rozsądny czas”, pod którym rozumiano 1-3 miesięcy ${ }^{71}$. Krótko po publicznych deklaracjach ważnych polityków, że mechanizm z Joaniny to zwycięstwo polskiej delegacji, okazało się, iż prezydent L. Kaczyński i szefowa MSZ A. Fotyga otrzymali mniej, niż spodziewali się dostać.

Chodziło o kontrowersyjny zapis „rozsądny czas”, który dla Unii Europejskiej oznacza kilka miesięcy, a dla polskiej delegacji możliwość blokowania decyzji w nieskończoność, dlatego Polska zakładała, że będzie walczyć o sprecyzowanie terminu w trakcie Konferencji Międzyrządowej.

Krótko po tym wydarzeniu Unia Europejska zaczęła bardzo intensywnie przygotowywać się do szczytu w Lizbonie, na którym miał zostać oficjalnie przyjęty traktat reformujący, zwany lizbońskim. Rząd cały czas upierał się jednak przy wpisaniu mechanizmu z Joaniny bezpośrednio do traktatu, a nie, tak jak chciały tego inne państwa, do towarzyszącej mu deklaracji.

Drugim postulatem, który wysuwał rząd, była sprawa przyznania Polsce prawa do posiadania stałego rzecznika generalnego w Europejskim Trybunale Sprawiedliwości. Wydawało się, że ten postulat zostanie spełniony, natomiast problemy mogą pojawić się w kwestii wpisania do traktatu Joaniny ${ }^{72}$. Wciąż zadawano sobie pytanie, czy na szczycie w Lizbonie zostanie oficjalnie przyjęty traktat reformujący. Wskazywano że największym „hamulcowym” procesu reformującego był polski rząd. Mimo wszystko przewodniczący Komisji Europejskiej J. M. Barroso sądził, że to nie będzie bitwa lizbońska, bowiem żaden z krajów nie chce doprowadzić do fiaska ${ }^{73}$.

\section{Szczyt Rady Europejskiej w Lizbonie}

W Lizbonie na szczycie Rady Europejskiej rozpoczęły się ostatnie negocjacje dotyczące traktatu reformującego. Dyskusja nie była łatwa, jednak doprowadziła do kompromisu. Przyjęto, że Unia Europejska będzie miała Traktat lizboński, a Polska

${ }^{69}$ Zob. „Rzeczpospolita” z 25 czerwca 2007 r.

70 Zob. P. Wroński, Fotyga: Jeszcze wyedukujemy Europe, „GW” z 29 czerwca 2007 r., s. 4.

71 Zob. Joanina z niespodzianka, „GW” z 28 czerwca 2007 r., s. 1.

72 Zob. D. Pszczółkowska, Fotyga: Krok do sukcesu w UE, „GW” z 16 października 2007 r., s. 10.

73 Zob. eadem, Unia idzie z Nicei do Lizbony, „GW” z 18 października 2007 r., s. 12. 
mechanizm z Joaniny. W sprawie Joaniny Polsce wyszli naprzeciw Francuzi, deklarując poparcie dla polskich postulatów. Ustalono jednak, że szczegóły mechanizmu z Joaniny pozostaną $\mathrm{w}$ deklaracji, ale do protokołu zostanie wpisana zasada, że mechanizm można zmienić tylko jednomyślnie ${ }^{74}$.

Traktat lizboński miał zostać podpisany 13 grudnia 2007 roku. Jego założenia usprawniały podejmowanie decyzji Unii, nadawały jej podstawę prawną, wprowadzały ministra spraw zagranicznych oraz prezydenta na 2,5 letnią kadencję, a także Kartę Praw Podstawowych ${ }^{75}$. Wierzono, że Unia dzięki nowemu traktatowi wreszcie wyjdzie z okresu kryzysu instytucjonalnego ${ }^{76}$, a sam dokument zacznie obowiązywać od $2009 \mathrm{roku}^{77}$.

Zanim jednak doszło do oficjalnego podpisania traktatu reformującego, w Polsce odbyły się przedterminowe wybory, które były po części wynikiem rozpadu koalicji rządzącej PiS-LPR-Samoobrona, a także doprowadziły do powstania mniejszościowego rządu J. Kaczyńskiego i w efekcie skrócenia kadencji parlamentu. Wybory wygrała Platforma Obywatelska, uzyskując 41,51 procent poparcia, z kolei na Prawo i Sprawiedliwość zagłosowało 32,11 procent wyborców. W tej sytuacji Platforma Obywatelska zawiązała koalicję z Polskim Stronnictwem Ludowym, a premierem został Donald Tusk.

Nowy premier zadeklarował, że Polska powinna jako pierwszy kraj w Unii Europejskiej ratyfikować traktat reformujący. Ponadto stwierdził, że należy diametralnie zmienić politykę zagraniczną, aby nie być krajem hamującym procesy integracji europejskiej i stosunki z innymi państwami ${ }^{78}$.

W podobnym duchu wypowiedział się prezydent Francji N. Sarkozy, twierdząc, że nowy rząd winien zerwać więzi z polityką prowadzoną przez PiS i zacząć konstruktywnie funkcjonować, a także współpracować z innymi krajami. Prezydent mówił też, że przed nowym rządem stoi wiele wyzwań, które nie zostały rozwiązane przez J. Kaczyńskiego, a koncentrują się wokół podpisania traktatu reformującego, przyjęcia Karty Praw Podstawowych, na podziale zadań w polityce zagranicznej kończąc ${ }^{79}$.

W stolicach europejskich przyjęto spokojnie kwestię ratyfikacji traktatu reformującego. Wynikało to stąd, że w 26 na 27 krajów Unii Europejskiej miał on zostać przyjęty przez parlamenty narodowe ${ }^{80}$.

12 grudnia 2007 roku Rada Ministrów udzieliła premierowi zgody na ratyfikację traktatu reformującego ${ }^{81}$. Na czele delegacji miał stanąć prezydent RP L. Kaczyński, który w imieniu polskiego Rządu negocjował jego warunki. Z kolei podpisany miał zostać przez premiera i ministra spraw zagranicznych.

74 Zob. J. Pawlicki, D. Pszczółkowska, Traktat Unii z Joaninq, „GW” z 19 października 2007 r., s. 12.

75 Karta Praw Podstawowych to katalog praw i wartości.

76 Zob. J. Pawlicki, D. Pszczółkowska, Europa ma nowy Traktat, „GW” z 20-21 października 2007 r., s. 10.

77 Rok 2009 był datą, do której wszystkie 27 państw członkowskich miało ratyfikować Traktat lizboński.

78 Zob. J. Pawlicki, Badźmy pierwsi w Unii, „GW” z 23 października 2007 r., s. 10.

79 Zob. P. Świeboda, Europejskie szczęście PO, „GW” z 29 października 2007 r., s. 21.

80 Zob. J. Pawlicki, Jak przejdzie traktat lizboński, „GW” z 9 listopada 2007 r., s. 15

81 Zob. Ministrowie za traktatem reformujacym UE, ,GW” z 12 grudnia 2007 r., s. 5. 
L. Kaczyński stwierdził, że poleci na ceremonię podpisania traktatu, a także na odbywający się szczyt w Brukseli, co doprowadziło do kolejnego konfliktu na linii prezydent-premier. D. Tusk orzekł, że posiedzenia Rady Europejskiej to domena rządu, a nie prezydenta, i nie będzie żadnych zmian w tej kwestii ${ }^{82}$. W efekcie rozmów premiera z prezydentem udało się jednak załagodzić sytuację i premier pojechał sam na szczyt Rady Europejskiej ${ }^{83}$. W mediach pojawiły się stwierdzenia, że L. Kaczyński ustąpił i będzie przewodniczył delegacji na szczycie Unii Europejskiej, ale nie pojedzie do Brukseli. Twierdzono, że to dobry krok w kierunku spójnej polityki zagranicznej ${ }^{84}$.

13 grudnia 2007 roku premier D. Tusk i minister spraw zagranicznych Radosław Sikorski złożyli podpisy pod traktatem reformującym, którego oficjalna nazwa brzmiała Traktat z Lizbony zmieniajacy Traktat o Unii Europejskiej i Traktat ustanawiajacy Wspólnotę Europejska.

Założono, że traktat wejdzie w życie 1 stycznia 2009 roku, pod warunkiem złożenia do depozytu dokumentów ratyfikacyjnych wszystkich państw członkowskich. W przeciwnym wypadku traktat wejdzie w życie ,,pierwszego dnia miesiąca następującego po złożeniu dokumentu ratyfikacyjnego przez Państwo-Sygnatariusza, które jako ostatnie dopełni tej formalności ${ }^{\prime} 85$.

Zadowolenie z podpisania nowego traktatu reformującego wyrażali przywódcy wszystkich państw członkowskich. D Tusk mówił, że jest wzruszony. Twierdził wręcz że „to bardzo ważny dzień dla Polski”. Mówił: „Cieszę się, bo 13 grudnia to dla ludzi mojego pokolenia zamknięcie pewnego etapu". Z kolei Sikorski oświadczył, że ten dzień kojarzy mu się z wejściem Polski do NATO w 1997 r. Twierdził, iż „to sukces Europy i Polski. Unia będzie bardziej demokratyczna, spójna, bardziej zdolna do działania" ${ }^{" 86}$. Niemałe zadowolenia z podpisania traktatu wyrażała delegacja niemiecka. A. Merkel uznała ów dokument za przełomowy, zapewniający Unii Europejskiej sprawność w działaniu. Traktat był także fetowany w Polsce przez opozycję, w szczególności przez były rząd J. Kaczyńskiego, uznany za olbrzymi sukces, potwierdzający skuteczność twardej dyplomacji.

O traktacie wypowiadali się również inni politycy. Były prezydent Francji Valéry Giscard d'Estaing stwierdził, iż traktat reformujący ma dziewięć kluczowych punktów, które są spójne z projektem konstytucji europejskiej przygotowanym pod jego przewodnictwem. Przede wszystkim Unia uzyskuje osobowość prawna, stabilnego prezydenta zamiast prezydencji, a także unijnego szefa dyplomacji. Ponadto traktat bardziej precyzyjnie rozdziela kompetencje między państwami członkowskimi a Komisją Europejska, wprowadza w Unii procedurę legislacyjną na wzór państw demokratycznych z terminami „ustawa”, a nie „dyrektywa”. W tekście traktatu zapisano, że parlamenty narodowe będą mogły kontrolować realizację unijnej zasady subsydiarności; zmniejsza ilość komisarzy; utrzymuje monopol inicjatywy ustawodawczej w rękach Komisji

82 Zob. P. Wroński, Prezydent chce lecieć i do Lizbony i do Brukseli, „GW” z 12 grudnia 2007 r., s. 1.

83 Zob. idem, W Lizbonie duet, w Brukseli solo, „GW” z 13 grudnia 2007 r., s. 5.

${ }^{84}$ Zob. Prezydent i premier wyszli z zakrętu, „GW” z 13 grudnia 2007 r., s. 1.

85 Treaty of Lisbon, „Official Journal of the European Union C 306” z 17 grudnia 2007 r.

86 J. Pawlicki, Europa świętuje traktat, „GW” z 14 grudnia 2007 r., s. 10. 
Europejskiej oraz wprowadza zasadę podwójnej większości w głosowaniach ${ }^{87}$. V. Giscard d'Estaing ogólnie pozytywnie ocenił nowy traktat reformujący, jednak przyznał, iż Europa potrzebuje dyskusji, w jakim kierunku dalej się rozwijać, jak stać się potęgą światową ${ }^{88}$.

W podobnym tonie wypowiadał się Jose Ignacjo Torreblanca, wiceszef Europejskiej Rady ds. Stosunków Zagranicznych, twierdząc, iż traktat daje wiele nowych możliwości przekształcenia Unii Europejskiej w jednolity organizm polityczny, jednak wiele zależy od przywódców państw, którzy będą wdrażać jego postanowienia w życie ${ }^{89}$.

Wydawało się, że nowy traktat reformujący stanowi nowąjakość i okres w funkcjonowaniu Unii Europejskiej. Jego wejście w życie miało raz na zawsze rozstrzygnąć spory akademickie na temat roli i statusu prawnego Unii Europejskiej. Był to także warunek dalszych ewentualnych rozszerzeń UE oraz jej sprawnego systemu instytucjonalnego, co już przy 27 państwach członkach wydawało się trudne. Wszystkie te niedomagania miał niwelować Traktat lizboński. Jego podpisanie zakończyło pewien etap merytorycznej, trwającej od kilku lat reformy traktatowej. Wiązało się to z nowym spojrzeniem na przyszłość Unii Europejskiej.

Jednak z drugiej strony długoletni proces reform traktatowych spowodował pewnego rodzaju ,wypalenie emocjonalne”, które nie sprzyja generowaniu nowych twórczych koncepcji. Podkreślić należy także, że otwarty jest ciagle problem zdefiniowania, akceptacji i wdrożenia ,finalité politique”.

W 2008 roku Traktat lizboński był już dokumentem podpisanym przez wszystkie państwa członkowskie. W dyskusjach politycznych zaczęły pojawiać się nowe elementy dotyczące w szczególności procedury ratyfikacyjnej oraz wyboru prezydenta i wysokiego przedstawiciela ds. polityki zagranicznej i bezpieczeństwa. Jako pierwsi, o czym już wspomniano, traktat ratyfikowali Węgrzy. 325 parlamentarzystów było za traktatem, a tylko pięciu przeciw ${ }^{90}$. Tym samym w Polsce rozpoczęła się dyskusja dotycząca ratyfikacji. Sejm opowiedział się za jak najszybszą ratyfikacją, uznając, że traktat przyczyni się do poprawy efektywności Unii Europejskiej oraz pozwoli na wzmocnienie jej roli w świecie ${ }^{91}$.

Pojawiły się jednak kraje, które zaczęły „ociągać się” z przeprowadzeniem procedur ratyfikacyjnych $\mathrm{w}$ swoich państwach. Jednym $\mathrm{z}$ nich były Czechy. Otwarcie mówiono, że mogą one nie zdążyć z ratyfikacją do końca 2008 roku. Prezydent Francji Nicolas Sarkozy chciał, aby nazwiska prezydenta i wysokiego przedstawiciela były znane już w drugiej połowie 2008 roku $^{92}$.

Było to po części związane z mającymi się odbyć wyborami do Parlamentu Europejskiego w 2009 roku oraz wynikającymi z tego zmianami w instytucjach europejskich.

\footnotetext{
87 Zob. Ł. Lipiński, Europa, traktat na gruzach konstytucji, „GW” z 14 grudnia 2007 r., s. 1.

88 Zob. Valery Giscard D'Estaing, Traktat wedtug Giscarda d'Estaing, „GW” z 14 grudnia 2007 r., s. 10.

89 Zob. J. I. Torreblanca, Quo vadis, Europo, „GW” z 14 grudnia 2007 r., s. 10.

90 Zob. Wegry ratyfikowaty traktat z Lizbony, „GW” z 18 grudnia 2007 r., s. 10.

91 Zob. Sejm: Traktat wzmocni UE, „GW” z 18 grudnia 2007 r., s. 16. Zob. też: A. Łada, Traktat Lizboński długo oczekiwana reforma funkcjonowania Unii Europejskiej, „Gazeta Prawna” z 12 października 2009 r., s. 1.

92 Zob. D. Pszczółkowska, Kto wybierze prezydenta Unii, „GW” z 8 lutego 2008 r., s. 10.
} 
Twierdzono nawet, że osoby na wymienione stanowiska zostaną wybrane przez prezydenta Francji i kanclerz Niemiec A. Merkel, którzy później będą przekonywać resztę krajów do swojego stanowiska. Jednak wydawało się, że taka forma raczej nie zdobędzie aprobaty krajów Unii Europejskiej ${ }^{93}$.

Do końca maja 2008 roku 17 krajów członkowskich Unii Europejskiej zaaprobowało traktat reformujący. Obawiano się, że państwem, które może odrzucić dokument, będzie Irlandia. Sytuacja ta po części wynikała z rysującej się zmiany proporcji między zwolennikami a przeciwnikami. Doprowadziło do to licznych komentarzy ze strony dużych państw członkowskich skierowanych w stronę Irlandczyków.

Szef Ministerstwa Spraw Zagranicznych Francji Bernard Kouchner twierdził, że nieprzyjęcie przez Irlandię Traktatu lizbońskiego spotka się z wielkim niezrozumieniem przez inne państwa członkowskie, a także doprowadzi do „samoukarania się” tego kraju. Nie sprecyzował jednak, na czym miałaby ta kara polegać. W podobnym tonie wypowiedział się szef Komisji Europejskiej José Manuel Barosso, twierdząc, iż za fiasko referendum zapłacą wszystkie kraje Unii Europejskiej ${ }^{94}$.

Słowa przywódców wskazywały na rysujący się kryzys polityczny, który ogarniał państwa Unii Europejskiej, a mógł osiagnąć punkt kulminacyjny w przypadku odrzucenia traktatu przez Irlandię. Był to także pewien wyraz bezradności, jaka ogarnęła kraje członkowskie, choć w kuluarach mówiło się o planie „B” w przypadku odrzucenia przez Irlandczyków traktatu ${ }^{95}$. Uważano, że gdyby 26 państw przyjęło traktat, wtedy Unia Europejska znalazłaby przepis prawny, na podstawie którego dokument wszedłby w życie ${ }^{96}$.

Podobnie polscy politycy dość żywo komentowali obawy innych krajów co do przyjęcia traktatu. Marszałek Senatu B. Borusewicz sądził, że możliwy jest scenariusz, w którym dalszy rozwój integracji będzie odbywał się poza Irlandią. Premier D. Tusk uważał, że Europa na pewno znajdzie jakiś sposób na wprowadzenie traktatu w życie. Premier sądził, że jego odrzucenie przez Irlandczyków nie oznacza, iż jest on z zasady zły, ale być może niektóre jego zapisy nie odpowiadają części opinii publicznej w Irlandii. Marszałek Sejmu B. Komorowski uważał, że możliwe będzie rozwiązanie problemu na gruncie prawa irlandzkiego. Trochę bardziej sceptyczny okazał się poseł PiS Paweł Kowal, twierdząc, iż należy uszanować wolę społeczeństwa irlandzkiego ${ }^{97}$.

\section{Konsekwencje odrzucenia Traktatu lizbońskiego w Irlandii}

Referendum w Irlandii rozpoczęło się 9 czerwca 2008 roku. Jako pierwsi do głosowania przystapili mieszkańcy trzech wysepek u wybrzeży hrabstwa Donegal - Arranmore, Gola i Inishfree ${ }^{98}$. W pozostałej części kraju referendum odbyło się 12 czerwca

\footnotetext{
93 Ibidem.

94 Zob. J. Pawlicki, Francja straszy Irlandię, „GW” z 10 czerwca 2008 r., s. 12.

95 Twierdzono, że w przypadku irlandzkiego „nie” Francja i Niemcy będą robić wszystko, aby proces ratyfikacji się nie zatrzymał.

${ }^{96}$ Chodziło o możliwość zastosowania klauzuli „opt-in”, czyli opcji przyłączenia się Irlandii do traktatu w terminie późniejszym.

97 Zob. Komentarze polskich polityków, „GW” z 14-15 czerwca 2008 r., s. 10.

98 Zob. Pierwsi Irlandczycy już głosuja, http://www.rp.pl/artykul/146082.html, 22.11.2008.
} 
2008 roku $^{99}$. Za odrzuceniem dokumentu głosowało 53,4\% wyborców, natomiast za jego przyjęciem $46,7 \%{ }^{100}$.

Odrzucenie Traktatu z Lizbony wywołało szok wśród polityków w Brukseli. Część eurodeputowanych wezwała do kontynuowania ratyfikacji. Inni apelowali o specjalny szczyt UE. Premier Irlandii Brain Cowen oznajmił, że szanuje wolę społeczeństwa i zamierza zastanowić się nad możliwością rozwiązania tego problemu ${ }^{101}$.

Posłowie z Parlamentu Europejskiego byli podzieleni w kwestii dalszych poczynań. Socjaliści uważali, że należy kontynuować proces ratyfikacji, z kolei liberałowie sądzili, że należy zorganizować specjalny szczyt, który będzie poświęcony roli i znaczeniu wyniku irlandzkiego na pozostałe kraje członkowskie, a w efekcie na Unię Europejską ${ }^{102}$.

Premier D. Tusk uważał, że wynik irlandzkiego referendum wcale nie musi przekreślać szans na wprowadzenie traktatu w życie. Twierdził, iż można znaleźć pewne rozwiązania, które uwzględnią obawy Irlandczyków, a jednocześnie nie naruszą całej reformy traktatowej ${ }^{103}$. W podobnym tonie wypowiadał się Mikołaj Dowgielewicz, mówiąc, iż nie takie problemy rozwiązywała Unia Europejska i na pewno wybrnie również z tej sytuacji 104 .

Podobnego zdania byli niezależni eksperci, twierdząc, że klęska referendum w Irlandii to wielkie rozczarowanie dla społeczeństwa. Szczególnie podkreślał to Jacques Rupnik, francuski politolog. Natomiast niemiecki analityk Cornelius Ochmann mówił, że porażka traktatu to problem, ale jeszcze nie katastrofa, chociaż może do niej dojść, kiedy kraje członkowskie pójdą tą samą drogą co Irlandczycy ${ }^{105}$.

Po negatywnym wyniku referendum do grona sceptyków dołączył prezydent Polski L. Kaczyński oraz prezydent Czech V. Klaus. Obawiano się, że te dwa kraje mogą zadać ostateczny cios traktatowi. W międzyczasie Europa przygotowywała plan „D”, w którym reszta krajów Unii Europejskiej miała ratyfikować traktat, a rząd irlandzki przedstawić Komisji Europejskiej pakiet propozycji, na podstawie których można by zmienić stanowisko swoich wyborców ${ }^{106}$. Propozycje te były dyskutowane na specjalnym szczycie Unii Europejskiej ${ }^{107}$.

Odbywające się spotkanie szefów rządów i państw w Brukseli skoncentrowane było na rozwiązaniu problemu z ratyfikacją Traktatu lizbońskiego. Premier Irlandii B. Cowen thumaczył, że lada dzień rozpocznie konsultacje z innymi politykami, aby znaleźć rozwiązanie i sprawić, by Irlandia nadal odgrywała istotną rolę w Unii Europejskiej. Szczyt przebiegał w spokoju, nikt nie naciskał na Irlandię, by podjęła jakieś rady-

99 Zob. Irlandia: Referendum ws. traktatu 12 czerwca?, http://www.tvn24.pl/12691,1544611, wiadomosc.html, 22.11.2008.

100 Zob. „Gazeta Prawna” z 13 czerwca 2008 r.

101 Zob. Irlandia po referendum, „Wprost” z 17 czerwca 2008 r.

102 Zob. Irlandia po referendum, op. cit.

103 Zob. J. Bielecki, Trzy scenariusze przyszłości Europy, „Dziennik” z 13 czerwca 2008 r.

104 Zob. J. Pawlicki, Nie takie przeszkody Unia pokonała, ,GW” z 14-15 czerwca 2008 r., s. 10

105 Zob. D. Pszczółkowska, Irlandia odrzuciła traktat, „GW” z 14-15 czerwca 2008 r., s. 8.

106 Zob. Kryzys irlandzki widziany z Berlina, „GW” z 20 czerwca 2008 r., s. 14.

107 Ibidem, s. 14. A. Merkel twierdziła wręcz, że Irlandii należy dać kolejną szansę na naprawienie swojego błędu. 
kalne decyzje. Przewodniczący Komisji Europejskiej J. M. Barosso stwierdził, że dostanie ona czas, by zdecydować, co będzie dalej w kwestii traktatu. W podobnym tonie wypowiedziała się A. Merkel. Premier D. Tusk postulował, aby nie popędzać Irlandczyków $^{108}$. W efekcie założono, iż jeśli do października 2008 roku traktat zostanie ratyfikowany przez 26 z 27 państw, przywódcy krajów Unii Europejskiej zwrócą się do Irlandii o podjęcie ostatecznej decyzji w sprawie traktatu ${ }^{109}$.

Szefowie państw i rządów na szczycie w Brukseli mogli w rzeczywistości zadać sobie pytanie: dlaczego europejskie społeczeństwa nie chcą się podpisać pod czymś, co im fundują elity polityczne? ${ }^{110}$ Mogli również dojść do przekonania, że Unię Europejską bardzo łatwo zgubi brak solidarności wśród krajów członkowskich.

W wywiadzie dla „Gazety Wyborczej” premier D. Tusk stwierdził, że w wyniku odrzucenia Traktatu lizbońskiego przez Irlandczyków termin 1 stycznia 2009 roku jako data przyjęcia traktatu staje się mało prawdopodobny. Sądził, że jeżeli traktat nie wejdzie w życie, nie będą mogły odbyć się wybory do Parlamentu Europejskiego zgodnie z nowymi regulacjami. Premier odniósł się także do kwestii podpisania traktatu przez prezydenta i stwierdził, że L. Kaczyński powinien go jak najszybciej podpisać, mimo wielu nieodpowiedzialnych wypowiedzi ze strony jego brata Jarosława czy środowiska Prawa i Sprawiedliwości ${ }^{111}$.

Tymczasem w Europie doszło do przełomowego wydarzenia. Prezydent Niemiec H. Kostler w wyniku skargi wniesionej do Trybunału Konstytucyjnego przez kilku posłów Bundestagu wstrzymał się z podpisem traktatu do czasu wydania wyroku w tej sprawie $^{112}$. Zbiegło się to z objęciem półrocznego przewodnictwa w Unii Europejskiej przez Francję, która była gorącym zwolennikiem jak najszybszego przyjęcia traktatu reformującego ${ }^{113}$. Z kolei do grona państw eurosceptycznych dołączyły Czechy, w których prezydent Vaclav Klaus odmówił podpisania traktatu, a także Polska.

W wyniku wypowiedzi prezydenta L. Kaczyńskiego w mediach zaczęto spekulować o statusie Traktatu lizbońskiego. W jednym z wywiadów dla „Gazety Wyborczej” szefowa berlińskiego biura European on Foreign Relations Dominique Guerot stwierdziła, że teza prezydenta Kaczyńskiego o Traktacie lizbońskim jest bardzo kontrowersyjna i nic nie wskazuje na to, że traktat ten umarł śmiercią naturalną. Jednocześnie podkreśliła, że decyzja polskiego prezydenta to polski problem, który Polacy sami muszą rozwiązać ${ }^{114}$.

Prezydent wyjaśniał, iż podpisze traktat, kiedy nie będzie on bezprzedmiotowy. Mówił, że na razie w RFN go zakwestionowano, a w Irlandii odrzucono. L. Kaczyński uważał, iż w takim przypadku ratyfikacja nie ma sensu, co nie oznacza, że traktat jest zupełnie martwy. Swoją wypowiedzią próbował zmienić sens słów, które wywołały wiele polemik w poszczególnych stolicach europejskich ${ }^{115}$. O ratyfikację przez prezy-

\footnotetext{
Zob. D. Tusk, Nie naciskać na Irlandię, „GW” z 21-22 czerwca 2008 r., s. 14.

109 Zob. D. Pszczółkowska, Irlandzki szczyt Unii, „GW” z 20 czerwca 2008 r., s. 14.

110 Zob. P. Świeboda, Karawana jedzie dalej. Tylko dokad?, „GW” z 21-22 czerwca 2008 r., s. 25.

111 Zob. D. Tusk, Nie naciskać na Irlandię, op. cit., s. 14.

112 Zob. Niemcy. Bez Lizbony, „GW” z 1 lipca 2008 r., s. 10.

113 Zob. D. Pszczółkowska, Francja bierze Unię, „GW” z 1 lipca 2008 r., s. 9.

114 Ibidem.

115 Zob. Lech Kaczyński w obronie Irlandii wstrzymuje podpis, „GW” z 3 lipca 2008 r., s. 5.
} 
denta L. Kaczyńskiego zaapelowały partie polityczne w Sejmie. Przygotowano specjalną uchwałę wzywająca prezydenta do ratyfikacji traktatu ${ }^{116}$.

W Europie, w szczególności w Irlandii, nastroje były jeszcze gorsze. Mówiono, że jeżeli Irlandia zostanie zmuszona do kolejnego głosowania nad Traktatem lizbońskim, jeszcze raz powie głośno „nie”. W takiej sytuacji szefowie państw Unii Europejskiej zaczęli zastanawiać się nad inną formułą wprowadzenia w życie nowych rozwiązań ${ }^{117}$.

Kolejnym państwem, które opowiedziało się za przyjęciem dokumentu, były Włochy. Minister spraw zagranicznych Franco Fratini uznał, że Traktat lizboński jest narzędziem, dzięki któremu można budować silną polityczną Europę ${ }^{118}$. Z ciekawą inicjatywą wystapił prezydent N. Sarkozy. Polegała na tym, aby niektóre kraje UE wystawiały wspólnych komisarzy ${ }^{119}$. Inicjatywa ta miała być odpowiedzią na wątpliwości Irlandczyków dotyczące posiadania swego komisarza. Niestety, nie wszystkim krajom się to spodobało, a szczególnie przeciwni temu rozwiązaniu byli Austriacy ${ }^{120}$.

W kraju prezydent Kaczyński twardo trzymał się zdania, że dopóki Irlandia nie ratyfikuje traktatu, Polska również tego nie dokona. Dość duży wpływ na decyzje prezydenta, jak można mniemać, miało środowisko Radia Maryja oraz prawicy narodowej reprezentowanej przez Jerzego Roberta Nowaka. Twierdził on, że jeśli prezydent ugnie się pod dyktatem Brukseli i ratyfikuje traktat, to straci zaufanie środowiska radiomaryjnego, co z kolei może mieć negatywne konsekwencje dla Prawa i Sprawiedliwości w kolejnych wyborach parlamentarnych ${ }^{121}$. Na prezydenta zaczęto dość silnie naciskać, aby w końcu dokonał ratyfikacji traktatu. Pod apelem o niezwłoczną ratyfikację skierowanym do głowy państwa podpisało się 5,7 tysiąca osób, zarzucając L. Kaczyńskiemu, że nie wywiązuje się ze zobowiązań przyjętych w trakcie procesu negocjacyjnego w Lizbonie ${ }^{122}$.

Podobnych argumentów użył N. Sarkozy podczas wizyty w Polsce. Wtórował mu D. Tusk, sądząc, że prezydent nie będzie zwlekał z ratyfikacją. Podobnego zdania było polskie społeczeństwo. Z badań CBOS, przeprowadzonych w drugiej połowie 2008 roku, wynikało, że 52 procent badanych uważało, że prezydent powinien ratyfikować traktat, 14 procent było przeciwnego zdania, a 34 procent nie miało zdania na ten temat.

Z czasem Irlandia zaczęła zmieniać stanowisko w sprawie Traktatu. Irlandzki minister ds. europejskich Dick Roch w wywiadzie dla „Gazety Wyborczej” stwierdził, że

\footnotetext{
116 Zob. Sejm próbuje coś zrobić, „GW” z 3 lipca 2008 r., s. 4. Przeciw uchwale było Prawo i Sprawiedliwość.

117 Zob. D. Pszczółkowska, Irlandia jeszcze bardziej przeciwna Lizbonie, „GW” z 28 lipca 2008 r., s. 8.

11 Zob. Włochy. Lizbona ratyfikowana, „GW” z 1 sierpnia 2008 r., s. 10. Zob. też: Włochy mówia, że sq za Traktatem, „Dziennik” z 23 lipca $2008 \mathrm{r}$.

119 Na przykład Austria z Niemcami, trzy państwa Beneluksu mogłyby wystawiać wspólnych komisarzy, nazwanych półkomisarzami czy kombikomisarzami.

120 Zob. D. Pszczółkowska, Sorbozy: Pót komisarza na kraj Unii Europejskiej, „GW” z 8 sierpnia 2008 r., s. 14.

121 Zob. W. Szacki, Rydzyk pogrozil PiS i prezydentowi Kaczyńskiemu, „GW” z 25 sierpnia 2008 r., s. 8.

${ }_{122}$ Zob. Apel do Prezydenta Lecha Kaczyńskiego, „GW” z 29 sierpnia 2008 r., s. 1; http://www.dziennik.pl/polityka/article255237/Kaczynski_czeka_na_Irlandie.html, 20.10.2009.
} 
nie można wykluczyć, iż w odpowiednim momencie i okolicznościach konieczne będzie przeprowadzenie powtórnego referendum w sprawie Traktatu ${ }^{123}$. Stanowisko podtrzymywał tym, że już w 23 państwach przeprowadzono referendum, stąd oczekiwano że Irlandia również podejmie jakieś kroki w tej sprawie ${ }^{124}$. Obawiano się jednak, że Polska może odrzucić Traktat, co doprowadziłoby do destabilizacji Unii Europejskiej ${ }^{125}$.

Zaczęto nawet myśleć o wprowadzeniu pewnych awaryjnych scenariuszy. Jeden z nich koncentrował się na przedłużeniu o kilka miesięcy mandatu obecnej Komisji Europejskiej, inny zakładał powołanie nowej Komisji na mocy Traktatu nicejskiego ${ }^{126}$. Tymczasem na kolejnym szczycie unijnym przywódcy krajów UE zdecydowali, że w Irlandii odbędzie się jednak drugie referendum w sprawie przyjęcia traktatu ${ }^{127}$. Referendum miałoby się odbyć przed październikiem $2009 \mathrm{roku}^{128}$. UE obiecała Irlandii w zamian funkcję stałego komisarza i gwarancję, że nie będzie narzucać przepisów dotyczących aborcji czy podatków ${ }^{129}$. Traktat miałby wejść w życie do końca 2009 roku. Po tych ustaleniach głos zabrał L. Kaczyński, mówiąc, iż jeżeli Irlandia powie „tak”, to on sam natychmiast podpisze Traktat ${ }^{130}$.

Pod koniec 2008 roku panowało przekonanie, że to prezydent Francji nadał nowe życie traktatowi ${ }^{131}$. Dalsza praca należała do Czechów, którzy 1 stycznia 2009 roku objęli przewodnictwo w Unii Europejskiej. Czesi nie byli jednogłośni w kwestii Traktatu lizbońskiego. Przepychanki między czeskim premierem a prezydentem trwały do momentu, kiedy upadł rząd Mirka Topolanka ${ }^{132}$. W kwestii ratyfikacji Traktatu lizbońskiego wypowiadało się wielu analityków. Jedni z nich sądzili, że po prezydencji czeskiej nie należy spodziewać się niczego dobrego; z kolei inni twierdzili, że rząd premiera Topolanka nie miał mocnego oparcia i w końcu upadł, zwłaszcza że musiał się zmierzyć z eurosceptycznym prezydentem Klausem ${ }^{133}$. Obawiano się nawet, że największym hamulcowym procesu ratyfikacji traktatu reformującego będą właśnie Czechy ${ }^{134}$.

Mimo upadku rządu Topolanka V. Klaus był cały czas zażartym przeciwnikiem Traktatu lizbońskiego, chociaż oficjalnie temu zaprzeczał ${ }^{135}$. W jednym z wywiadów stwierdził, iż swój podpis pod traktatem uzależnia od referendum w Irlandii oraz od sta-

123 Zob. Czy Irlandia zagłosuje nad traktatem, „GW” z 26 sierpnia 2008 r., s. 8.

124 Zob. J. Pawlicki, Prezydent Portugalii: Nie dajmy Rosji dzielić Unii, „GW” z 2 września 2008 r., s. 10.

125 Zob. B. Kuraś, Boże, błogosław Europę, „GW” z 13-14 września 2008 r., s. 6.

126 Zob. S. Rozpędzik, Traktat Lizboński najwcześniej w 2010, „GW” z 19 września 2008 r., s. 13.

127 Zob. UE. Zostawić Irlandii komisarza, „GW” z 10 grudnia 2008 r., s. 13.

128 Zob. K. Niklewicz, D. Pszczółkowska, Lizbona wstaje z grobu, „GW” z 12 grudnia 2008 r.

129 Zob. eidem, Drugi bój o Lizbonę potwierdzony, „GW” z 14 grudnia 2008 r., s. 10.

130 Ibidem.

131 Zob. Lizbon Story, czyli jak Francja wskrzesiła nieboszczyka, „GW” z 31 grudnia 2008-1 stycznia 2009 r., s. 13.

132 Zob. L. Palata, P. Świeboda, P. M. Kaczyński, M. Meckel, J. Quatremer, Topolanek padt w Pradze, „GW” z 25 marca 2009 r., s. 7.

133 Ibidem.

134 Zob. D. Pszczółkowska, Lizbona utopie w Pradze, „GW” z 26 marca 2009 r., s. 8.

135 Prezydent uzależniał podpisanie Traktatu od czterech kwestii: od wyroku niemieckiego Trybunału Konstytucyjnego, akceptacji go przez Irlandczyków, orzeczenie czeskiego Trybunału Konstytucyjnego oraz od podpisu przez Lecha Kaczyńskiego. Zob. L. Palata, Klaus podpisze Lizbonę, jak podpisze Kaczyński, „GW” z 25 czerwca 2009 r., s. 9. 
nowiska L. Kaczyńskiego ${ }^{136}$. W owym czasie orzeczenie w kwestii Traktatu lizbońskiego wydał również Niemiecki Trybunał Federalny, stwierdzając, że akt jest zgodny z konstytucją, a Niemcy muszą jedynie zmienić prawo, aby go definitywnie przyjąć ${ }^{137}$. A. Merkel oraz politycy byli zadowoleni $\mathrm{z}$ takiego rozwoju wydarzeń ${ }^{138}$. Z czasem Bundestag przyjął specjalne ustawy i dostosował prawo, tak więc droga do ratyfikacji w tym kraju została otwarta ${ }^{139}$.

Po rozpadzie rządu w Czechach wiadomo było także, iż Traktat lizboński nie będzie głosowany w izbie wyższej parlamentu, a także nie zostanie tak łatwo zaakceptowany przez Czechów ${ }^{140}$. Po krótkim czasie okazało się, że Czesi jednak są za przyjęciem Traktatu lizbońskiego. Senat zaakceptował jego postanowienia, a 44\% społeczeństwa zaczęło uważać, że zwlekanie z podpisem przez prezydenta V. Klausa szkodzi wizerunkowi państwa ${ }^{141}$.

Od tego momentu los dokumentu leżał w rękach Irlandczyków ${ }^{142}$. Za przyspieszeniem procedur ratyfikacyjnych zaczęły opowiadać się środowiska kościelne. W jednym z wywiadów dla „Gazety Wyborczej” bp. Pieronek stwierdził, że Europa bez Lizbony nie istnieje i obowiązkiem wszystkich chrześcijan jest poparcie Traktatu $^{143}$.

Opinie na temat Traktatu powoli zmieniały się także w samej Irlandii. Jej przywódcy jednak zaczęli uzależniać ratyfikację dokumentu od pewnych warunków. Między innymi chcieli zapewnień, że Unia Europejska nie będzie próbować zmienić ich wojskowej neutralności i że nie wymusi zmian w podatkach ani prawie rodzinnym. Z kolei unijni dyplomaci naciskali na to, aby Irlandczycy wyznaczyli datę referendum. Wstępnie uzgodniono, że będzie to jesień 2009 roku $^{144}$.

W Irlandii rozpoczęła się prawdziwa kampania dotycząca przyjęcia Traktatu. Firma Rynair przeznaczyła pół miliarda euro na referendum w sprawie przyjęcia Traktatu lizbońskiego, a także 300 tys. euro na specjalne obniżki cen biletów. W ten sposób chciano udowodnić, że zwykli ludzie mogą też korzystać z dobrodziejstw integracji europejskiej. Oprócz Ryanaira kampanię na rzecz Traktatu zaczął prowadzić niemiecki koncern Intel, który zamierzał wydać na nią kilkaset tysięcy euro ${ }^{145}$. Po krótkim czasie

136 Zob. Największy eurosceptyk, „GW” z 26 marca 2009 r., s. 8.

137 Germany finalises ratification of Lisbon Treaty, http://www.independent.ie/breaking-news/ world-news/europe/germany-finalises-ratification-of-lisbon-treaty-1897283.html, 29.09.2009.

138 Zob. B. T. Wieliński, Niemcy hamuja Lizbonę, „GW” z 1 lipca 2009 r., s. 8.

139 Zob. Niemcy prawie w Lizbonie, „GW” z 28 sierpnia 2009 r., s. 8.

140 Zob. L. Palata, Dlaczego nad Wettawa upadt rząd i kiedy będzie następny, ,GW" z 26 marca 2009 r., s. 8; D. Pszczółkowska, Czy Lizbona utonie w Pradze, „GW” z 26 marca 2009 r., s. 1; L. Palata, Czeski zamach na Europe, ,GW” z 26 marca 2009 r., s. 2; eadem, Chmury nad Lizbona, „GW” z 27 marca 2009 r., s. 8.

141 http://www.wprost.pl/ar/173739/Czesi-chca-Traktatu-Lizbonskiego/, 20.10.2010.

142 Zob. D. Pszczółkowska, Lizbona zależy od Irlandii, „GW” z 7 maja 2009 r., s. 11.

143 Zob. K. Wiśniewska, Chrześcijanie za Lizbonq, „GW” z 19 maja 2009 r., s. 8.

144 Zob. Czym zapłacić za irlandzkie tak dla Traktatu z Lizbony, „GW” z 20 maja 2009 r., s. 12; D. Pszczółkowska, Irlandczycy do referendum, „GW” z 25 czerwca 2009 r., s. 9. Przyjęto, że Traktat lizboński będzie głosowany w Irlandii 2 października 2009 roku.

145 Zob. B. T. Wieliński, Uskrzydlona Lizbona, „GW” z 28 sierpnia 2009 r., s. 8. 
Irlandię dosięgnęły skutki kryzysu finansowego. Zaczęto się obawiać, że mogą one przełożyć się na poparcie dla Traktatu lizbońskiego.

W najnowszych sondażach „The Irish Times” Irlandczycy wciąż popierali Traktat, jednak liczba zwolenników gwałtownie spadała ${ }^{146}$. Za przyjęciem dokumentu było $46 \%$, przeciw $26 \%$, a reszta stanowiła elektorat niezdecydowany.

Wykres 1. Poparcie dla Traktatu lizbońskiego w Irlandii we wrześniu 2009 roku
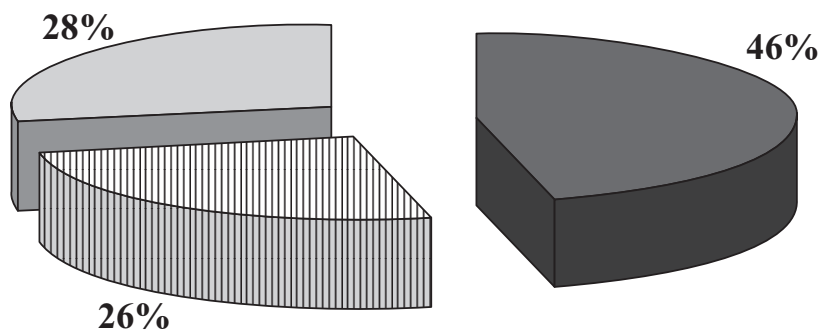

$\square$ Zwolennicy ratyfikacji Traktatu lizbońskiego

而 Przeciwnicy ratyfikacji TL

Niezdecydowani

Źródło: Opracowanie własne na podstawie: T. Bielecki, Irlandia powie Tak, „Gazeta Wyborcza” z 14 września 2009 r., s. 12.

Jak wskazywała „Gazeta Wyborcza”, poparcie w tym czasie zmniejszyło się o około 8 punktów procentowych i mogło dalej spadać, co byłoby pewnym zagrożeniem dla dalszych losów ratyfikacji ${ }^{147}$.

$\mathrm{Na}$ trzy tygodnie przed spodziewanym referendum w Irlandii przeprowadzono badania dotyczące spodziewanej frekwencji podczas głosowania nad Traktatem lizbońskim. Aż $62 \%$ obywateli zapowiedziało, że weźmie udział w głosowaniu, z czego 53,4\% stwierdziło, że poprze Traktat. Mimo że większość popierała dokument, zdarzały się też opinie negatywne. Zdarzały się głosy, że Traktat lizboński to fatalny krok wzmacniający biurokratów podejmujących decyzje za plecami społeczeństwa. Oficjalni przeciwnicy Traktatu wywodzili się z skrajnej katolickiej prawicy oraz lewicowej Sinn Féin. Do głosowania na ,tak" namawiał Irlandczyków nawet sam Lech Wałęsa ${ }^{148}$.

W ostatnim tygodniu przed referendum w sprawie Traktatu liczba przeciwników znacznie wzrastała, lecz nie przekroczyła 50\%. Zaczęto jednak spekulować, że Traktat może zostać odrzucony ${ }^{149}$. Tymczasem jego zwolennicy nawoływali do poparcia dokumentu, twierdząc, że tylko silna Unia może stawić czoło kryzysowi gospodarczemu ${ }^{150}$.

2 października 2009 roku odbyło się w Irlandii powszechne głosowanie nad przyjęciem Traktatu lizbońskiego ${ }^{151}$. Frekwencja wyniosła 58 procent, a za Traktatem opowiedziało się $67,1 \%$ głosujących $^{152}$.

\footnotetext{
146 Zob. http://www.independent.ie/, 2.09.2009.

147 Zob. T. Bielecki, Spada poparcie Irlandczyków dla Lizbony, „GW” z 5 września 2009 r., s. 8.

148 Zob. idem, Irlandia powie Tak, „GW” z 14 września 2009 r., s. 12.

149 Zob. idem, Ilu Irlandczyków powie nie w piatek, „GW” z 1 października 2009 r., s. 11.

150 Zob. idem, Irlandia głosuje Lizbonę, „GW” z 2 października 2009 r., s. 10.

151 Zob. idem, Irlandzki sqd nad Lizbona, „GW” z 3 października 2009 r., s. 7.

152 Zob. www.stosunkimiedzynarodowe.info/artykul,495,Sukces_referendum_ws_Traktatu_Lizbonskiego_w_Irlandii, 19.10.2009.
} 


\section{Wykres 2. Wyniki glosowania w sprawie Traktatu lizbońskiego w Irlandii w dniu 2 października 2009 roku}

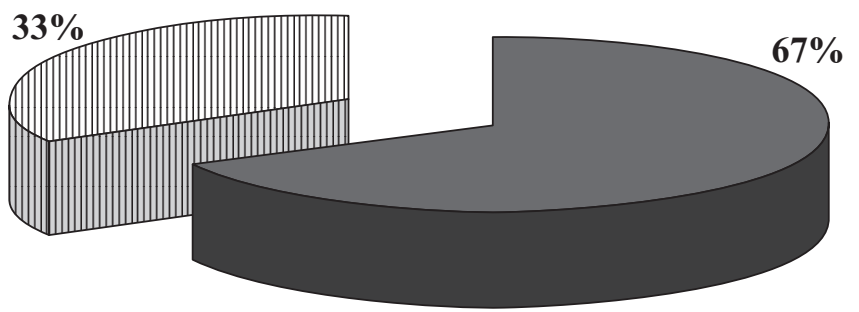

$\square$ Za Traktatem lizbońskim 四 Przeciw Traktatowi

Źródło: Opracowanie własne na podstawie: www.Stosunkimiedzynarodowe.info/artykul,495,Sukces_referendum_ws_Traktatu_Lizbonskiego_w_Irlandii, 19.10.2009.

Pierwszą reakcją na wynik irlandzkiego referendum było głębokie westchnienie i ulga. Wydaje się to zrozumiałe, bowiem fiasko referendalne zadałoby śmiertelny cios Traktatowi. Komentując wynik referendum, premier Brian Cowen stwierdził, że Irlandczycy zrobili decydujący krok ku silniejszej, bardziej sprawiedliwej i zarazem lepszej Irlandii, która będzie mogła funkcjonować w lepszej Unii Europejskiej. Z kolei J. Buzek mówił, iż Irlandczycy zademonstrowali prawdziwe zaangażowanie w europejski projekt, dzięki czemu Unia Europejska stanie się bardziej efektywna, a współpraca krajów bardziej owocna ${ }^{153}$.

Wydaje się, że w referendum chodziło jednak nie tylko o Traktat. Kwestia jego przyjęcia bardziej koncentrowała się na wizerunku Europy oraz jej zdolności do posuwania się do przodu ${ }^{154}$. Irlandzkie „tak” otwarło drzwi do Europy, w której jest miejsce dla wszystkich narodów ${ }^{155}$. Sprawę wyniku referendum komentował szef serbskiej dyplomacji V. Jeremic, mówiąc, że Europejczycy powinni się teraz wywiązać z obietnicy danej krajom bałkańskim i przyjąć je w szeregi Unii Europejskiej. Ponadto z wypowiedzi analityków brukselskich można było wywieść, iż przyjęcie Lizbony będzie w przyszłości pewnym ułatwieniem w trakcie negocjacji dotyczących nowego budżetu UE na lata 2014-2020.

Komentując wynik referendum, były przewodniczący Parlamentu Europejskiego Pat Cox mówił, iż głosując za Traktatem lizbońskim, Irlandczycy wykazali się niezwykłą dojrzałością, bo zdołali oddzielić sprawę Traktatu forsowanego przez rząd Irlandii od oceny samego premiera, który jest skrajnie niepopularny. Nie ukarali go odrzuceniem Traktatu, bo zrozumieli, że znacznie bardziej niż premierowi zaszkodziliby samym sobie. P. Cox, mówiąc o podpisaniu Traktatu przez polskiego i czeskiego prezy$\operatorname{denta}^{156}$, był nieco zaniepokojony, jednak mówił, że wierzy w ich dobre intencje $\mathrm{e}^{157}$.

\footnotetext{
153 Ibidem.

154 Zob. J. Pawlicki, Teraz możesz działać już Unio, „GW” z 5 października 2009 r., s. 2.

155 Ibidem.

156 Zob. L. Palata, Unia wisi teraz na Klausie, „GW” z 5 października 2009 r.; Irlandia ratuje Li-
} zbone, s. 4.

${ }_{157}$ T. Bielecki, Europa wystuchała Irlandii i ma traktat, „GW” z 5 października 2009 r.; Irlandia ratuje Lizbonę, s. 5; B. T. Wieliński, M. Dowgielewicz, Berlin odetchnąt z wielkqulga, „GW” z 5 października 2009, s. 4. 
Po kilku dniach okazało się jednak, że V. Klaus nie zamierza tak szybko podpisywać dokumentu. Początkowo pewne opory miał także L. Kaczyński. Pytany o datę ewentualnego złożenia podpisu pod Traktatem odpowiadał, że zrobi to „niebawem”" ${ }^{\text {"158 }}$.

Wypowiedź ta wywołała dość negatywne emocje ze strony ekipy sprawującej władzę. Powtarzano, że prezydent nie dotrzymuje raz danego słowa. Na L. Kaczyńskiego naciskało także środowisko Radia Maryja, które twierdziło, że podpisanie Traktatu lizbońskiego jest zabójstwem dla Polski.

Polskie i czeskie przeciaganie ratyfikacji wstrzymywało wybór i obsadzenie przez Szwecję stanowiska unijnego szefa dyplomacji oraz przewodniczącego Rady Europejskiej nazywanego zgodnie z zapisem Traktatu Prezydentem Unii Europejskiej ${ }^{159}$.

Bruksela chciała wybrać swoich nowych przedstawicieli już zgodnie z założeniami Traktatu reformującego. Miałoby to nastapić pod koniec października 2009 roku. Austriacki kanclerz Werner Faymann zaapelował o tzw. plan B na wypadek, gdyby prezydent Klaus nie podpisał Traktatu lizbońskiego (plan ten ma polegać na zmianie obowiązującego Traktatu nicejskiego). Jednakże V. Klaus zażądał dodatkowych gwarancji w postaci zabezpieczeń przed roszczeniami majattkowymi Niemiec. Tym samym użył najcięższej możliwej broni przeciw Traktatowi ${ }^{160}$.

Szczegółowe analizy zlecone przez Ministerstwo Spraw Zagranicznych w Czechach nie potwierdzały wątpliwości zgłaszanych przez prezydenta. Z kolei jakiekolwiek próby kontaktu Brukseli z czeskim prezydentem nie dawały rezultatu. Liczono, że rząd przekona V. Klausa do podpisania Traktatu. Gabinet, którym kierował Jan Fischer, próbował rozmawiać z prezydentem w kwestii podpisania dokumentu ${ }^{161}$. Prezydent zgłosił dodatkowe żądania, by Czechy, podobnie jak Polska i Wielka Brytania, zostały wyłączone $\mathrm{z}$ obowiązywania niektórych przepisów Karty Praw Podstawowych ${ }^{162}$.

Premier J. Fischer próbował przekonać przywódców Unii Europejskiej, by spełnili nowe żądania V. Klausa w sprawie Traktatu lizbońskiego. Owe żądania stały się oficjalnym stanowiskiem czeskiego rządu. Szef Komisji Europejskiej J. M. Barosso uznał żądania Czechów za nierealistyczne, bowiem wymagałyby one ponownej ratyfikacji przez wszystkie kraje ${ }^{163}$. Po tych roszczeniach czeskiego prezydenta J. M. Barosso zaczął wątpić, czy uda się zakończyć proces ratyfikacji do szczytu przywódców, który został zaplanowany w dniach 29-30 października 2009 roku.

158 Zob. P. Wroński, Prezydent odwleka podpisanie traktatu, „GW z 6 października 2009 r., s. 6.

159 Szerzej: J. Barcz, Unia Europejska na rozstajach. Dynamika i główne kierunki rozwoju reformy ustrojowej, Warszawa 2008.

160 Berlin jeszcze za czasów kanclerza Gerharda Schrödera zapewnił Pragę, że nigdy nie poprze majątkowych roszczeń wygnańców. Kanclerz A. Merkel, pierwsza szefowa niemieckiego rządu, trochę mówiąca po czesku, potwierdziła to. Zob. V. Klaus - prezydent, którego się wstydzę, „GW” z 12 października 2009 r., s. 15.

161 Twierdzono też, że V. Klaus, nie podpisując traktatu, naruszył swoje kompetencje, bo negocjowanie traktatów leży w gestii rządu. Zob. T. Bielecki, Czeski rząd szuka porozumienia, z Klausem, „GW” z 12 października 2009 r., s. 14.

162 O KPP szerzej: Karta Praw Podstawowych w europejskim i krajowym porzadku prawnym, red. A. Wróbel, Warszawa 2009.

163 Zob. T. Bielecki, UE nie ustępuje Klausowi, „GW” z 14 października 2009 r., s. 8. 
W Polsce nastapił przełom. Zgodnie z obietnicami po referendum w Irlandii prezydent L. Kaczyński podpisał Traktat lizboński. Stwierdził ostatecznie, że jest on korzystny dla Polski. Przypomniał, że z czternastu polskich postulatów, zostało przyjęte trzynaście ${ }^{164}$. Chwalił stanowczość poprzedniego rządu, a także wspomniał o pierwszym niekomunistycznym rządzie T. Mazowieckiego, który zainicjował cały proces integracji Polski z Unią Europejską ${ }^{165}$. Przyjęcie Traktatu lizbońskiego kończyło historyczny proces rozszerzenia Unii Europejskiej o dziesięć nowych krajów członkowskich. Miało ono także wpływ na realizację zasady solidarności energetycznej, wpłynęło też na ważną dla Polski Wspólną Politykę Zagraniczną i Obrony oraz na politykę konkurencyjności.

\section{Podsumowanie}

Pytanie, jakie zadają sobie obecnie politycy, koncentruje się na zagadnieniu dalszego przebiegu procedur przyjmowania Traktatu lizbońskiego. Czy V. Klaus podpisze dokument? Jakie dodatkowe problemy może napotkać wchodzący w życie Traktat? W obecnej sytuacji Jan Barcz twierdzi, iż możliwe są trzy scenariusze dalszego działania.

- wariant pierwszy: kontynuowanie procesu ratyfikacji Traktatu lizbońskiego aż do jego wejścia w życie, co w obecnej sytuacji politycznej jest najbardziej prawdopodobne;

- wariant drugi: porzucenie Traktatu z Lizbony i podjęcie prac nad nowym traktatem rewizyjnym, co obecnie jest najmniej prawdopodobne;

- wariant trzeci: porzucenie Traktatu z Lizbony i pozostanie przy obecnie obowiązujących traktatach w brzmieniu nadanym przez Traktat z Nicei ${ }^{166}$.

Jeśli przyjrzeć się tym trzem rozwiązaniom, to można wskazać, że wariantem najbardziej optymalnym dla Polski jest wariant pierwszy, a więc akceptacja Traktatu lizbońskiego.

Traktat ten prowadzi do umocnienia spójności wewnętrznej Unii Europejskiej, tworząc jednolitą organizację międzynarodową. Ponadto zwiększa liczbę obszarów, w których decyzje będą podejmowane w Radzie większością kwalifikowaną oraz wprowadza zmodyfikowaną tzw. podwójną większość w tej mierze. Traktat wzmacnia legitymizację demokratyczną Unii Europejskiej, umacniając rolę parlamentów narodowych, które będą kontrolować podejmowanie decyzji ważnych dla Unii. Traktat ustanawia również solidny fundament dla rozwoju Wspólnej Polityki Zagranicznej i Bezpieczeństwa oraz otwiera nowe możliwości dla rozwoju polityki sąsiedztwa ${ }^{167}$.

\footnotetext{
164 Wśród nich: przedłużenie nicejskiego systemu liczenia głosów praktycznie do 2017 r. oraz wprowadzenie protokołu z Joaniny.

165 Zob. P. Wroński, Lizbona nasza. Teraz hamuje Klaus, „GW” z 12 października 2009 r., s. 8. Mimo że L. Kaczyński podpisał Traktat, 60 posłów Prawa i Sprawiedliwości związanych z Radiem Maryja skierowało do Trybunału Konstytucyjnego wniosek o zbadanie zgodności Traktatu Reformującego z Konstytucją RP.

${ }_{166}$ Zob. J. Barcz, Unia Europejska na rozstajach. Dynamika i główne kierunki rozwoju reformy ustrojowej, Warszawa 2008, s. 244.

167 Ibidem, s. 169.
} 
Pozostałe przytoczone warianty obarczone są licznymi mankamentami i potencjalnymi zagrożeniami, które mogą spowolnić proces dalszej integracji europejskiej. Zatem w interesie wszystkich krajów członkowskich leży, aby Traktat lizboński został jak najszybciej ratyfikowany i wszedł w życie. Tego oczekują siły polityczne w kraju i Europie. Bez podpisu prezydenta V. Klausa wejście w życie Traktatu lizbońskiego nie jest jednak możliwe. 